\title{
Determinants of Health System Performance in Europe: A Study Based on Clustering Analysis
}

\author{
Pınar Yalçın Balçık ${ }^{1}$ (D) , Şenol Demirci ${ }^{1}$ (iD) , Murat Konca ${ }^{1}$ (iD
}

${ }^{1}$ Hacettepe Üniversitesi, İktisadi ve İdari Bilimler Fakültesi, Sağlık Yönetimi Bölümü, Ankara, Türkiye

PInar YALÇIN BALÇIK, Doç. Dr. Şenol DEMIRCi, Arş. Gör. Murat KONCA, Dr.

Correspondence: Pınar Yalçın Balçık Hacettepe Üniversitesi, İktisadi ve İdari Bilimler Fakültesi, Sağlık Yönetimi Bölümü, Ankara, Türkiye

Phone: -

E-mail: pinar.yalcin.balcik@gmail.com

\begin{abstract}
Health system performance is influenced by many factors such as behavioral and educational factors other than health system indicators. The aim of this study was to evaluate the effects of behavioral risk factors and educational factors on the health system performance in European Union member and candidate countries. Clustering analysis method was employed in the study. Firstly, clustering analysis was performed using health indicators and then, indicators related to behavioral risk factors and education were included in the analysis and it was investigated whether indicators related to behavioral risk factors and education affected the clusters formed by using health indicators. 4 clusters were formed in the clustering analysis using the health indicators, 5 clusters were formed in the clustering analysis with the addition of indicators related to behavioral risk factors to the health indicators and finally 5 clusters were formed in the clustering analysis with the addition of indicators related to education to the health indicators. It was seen that behavioral risk factors and educational indicators caused changes in clusters formed of countries. Countries that want to improve their health status should take into account behavioral risk factors and the impact of education on health status.
\end{abstract}

Keywords: Clustering analysis, health systems, performance management
Avrupa'da Sağlık Sistemi Performansının Belirleyicileri: Kümeleme Analizine Dayalı Bir Çalışma

ÖZET

Sağlık sistemi performansı, sağlık sistemi göstergeleri dışında davranışsal ve eğitimsel faktörler gibi birçok faktörden etkilenir. Bu çalışmanın amacı, davranışsal risk faktörleri ve eğitim faktörlerinin Avrupa Birliği üyesi ve aday ülkelerde sağlık sistemi performansı üzerindeki etkilerini değerlendirmektir. Araştırmada kümeleme analizi yöntemi kullanılmıştır. Öncelikle sağlık göstergeleri kullanılarak kümeleme analizi yapılmış, ardından analize davranışsal risk faktörleri ve eğitime ilişkin göstergeler dahil edilmiş ve davranışsal risk faktörleri ve eğitime ilişkin göstergelerin sağlık göstergeleri kullanılarak oluşturulan kümeleri etkileyip etkilemediği araştırılmıştır. Sağlık göstergeleri ile yapılan ilk kümeleme analizinde 4 küme oluşmuş, davranışsal risk faktörlerine ilişkin göstergelerin sağlık göstergelerine eklenmesi ile 5 küme oluşmuş ve son olarak eğitimsel göstergelerin sağlık göstergelerine eklenmesi ile yine 5 küme oluşmuştur. Davranışsal risk faktörlerinin ve eğitim göstergelerinin oluşan kümelerde değişikliklere neden olduğu görülmüştür. Sağlık statüsünü iyileştirmek isteyen ülkeler, davranışsal risk faktörlerinin ve eğitimin sağlık statüsü üzerindeki etkisini dikkate almalıdır.

Anahtar Kelimeler: Kümeleme analizi, sağlık sistemleri, performans yönetimi 
$\mathrm{H}$ ealth systems are the structures that involve all the activities necessary to protect or improve community health. The main purpose of health systems is to increase the health status of societies, but also to meet their expectations and to provide justice in financing in doing so (1). Health systems include resources, organizations, financing mechanisms, and governance models that responsible for the delivery of health care services to the population (2). Demonstrating the extent to which a health system achieves its goals requires performance measurements in health systems and it can be said that there are various methods in this regard. Among these methods, benchmarking can be seen as a powerful tool for decision-makers (3). The use of benchmarking by political decision-makers in the process of determining health policies is a method that has been used for many years (4).

Performance measurement is the assessment of the difference between the production of a person, institution, region or country with a duty to produce goods or services and the predetermined production targets through analytical processes (7). Performance measurement in health systems can be defined as monitoring and evaluating the effectiveness and efficiency of the services provided by the national health systems in meeting the needs and expectations of patients (3). Performance measurement studies in health systems offer benefits to people in decision-making mechanisms in health system on various issues. For example, whether health systems show progress or regress in terms of performance over time can be demonstrated by performance measurements. Similarly, performance improvement can be achieved by taking countries with high health system performance as an example with performance measurements based on the comparison of homogeneous health systems. Another benefit of performance measurement in health systems is that it can enable to determine to what extent the goals by performance measurement have been achieved. Other than these, performance measurements in health systems reveals the deficiencies and strengths, helps to design reform movements, increases accountability, provides evidence-based policies and makes it possible to direct resources to correct expenditures $(3,15,33)$.
It is difficult to determine whether health systems can achieve the predetermined objectives, since some factors other than health care services also affect the outcomes of health systems. So, performance measurements in health systems are difficult (8). Comparing countries with similar socioeconomic structures in performance measurement in health systems can help to overcome this difficulty.

While the history of performance measurement in health systems has been quite old $(9,10)$; it is possible to conclude that an increasing interest in this issue has been observed among the people involved in the decision-making mechanisms (6), because those who take part in decision-makers in the mechanism gave importance and care the impact of the performance of health systems (11). The reasons for increasing interest in performance measurement in health systems can be grouped into two groups as demand-side reasons and supply-side reasons. Demand-side reasons includes increased cost constraint pressure, increased awareness of patients, increased control and surveillance activities for health service providers and increased level of accountability expected from service providers $(12,13)$. The main supply-side reason, which prepares the ground for increasing the interest in performance measurement in health systems, is that data access becomes cheaper and easier due to the development of information technologies (3).

The fact that the accessing data has become easier has enabled the increment of numbers of the studies comparing the performance of the health systems of countries. When the basic methods used in these studies are examined; it is possible to say that some parametric and nonparametric methods such as Data Envelopment Analysis (DEA), Malmquist Total Factor Productivity Analysis (MTFP), Stochastic Frontier Analysis (SFA), Least Squares Regression (LSR) have come to the fore $(6,7,14,15)$. Apart from the aforementioned methods, there are several studies that show similarities and differences of regions or countries in terms of health system by benefiting from clustering analysis and thus provide information about the health system performance of regions or countries (16-23). 
As stated in Lalonde Report (1974), health systems are affected not only by health care services but also by many other factors, especially educational and socioeconomic factors (5). From this, it can be concluded that the performance of a health system is affected not only by health care services but also by many other factors (3). It is possible to see some studies supporting this view in the literature. For example, according to the findings of Samut and Cafri (2016), Afonso and Aubyn (2011), Moran and Jacobs (2013), Asghar, Rehman and Ali (2019), Ahmed et al. (2019), Castaldo and Antonelli (2020), education, economic structure and behavioral risk factors affect the performance of health systems $(6,34-38)$. As can be seen, some indicators other than health care services have to take place in the performance measurements specific to health systems.

In this study, the performance of health systems of the European Union (EU) member and EU candidate countries was revealed via clustering analysis. In this context, a clustering analysis was performed based on health indicators in the first step and then a second and a third clustering analysis were performed by adding indicators that are not directly related to health care services. Thus, whether the indicators that are not directly related to health care services influencing the clustering of countries was revealed.

\section{Methodology}

The research universe consists of 35 countries that are members or candidates of EU. The data of all countries except Kosovo were obtained and 34 EU member and candidate countries were included in the study sample. Variables used in the study were taken from databases of Organization of Economic Cooperation and Development Countries (OECD) (https://data.oecd.org/), United Nations (http://data.uis.unesco.org/), World Health Organization (WHO) (https://www.who.int/gho/en/) and World Bank (WB) (https://data.worldbank.org/). In the absence of data on the year taken, the data of the nearest year were evaluated. Information about the variables used in the study are given in Table 1.
Table 1. Variables employed in the study

\begin{tabular}{|c|c|c|}
\hline Variables & Explanation & Database (Year) \\
\hline $\begin{array}{l}\text { Number of } \\
\text { Physicians }\end{array}$ & $\begin{array}{l}\text { The number of physicians } \\
\text { per } 1000 \text { individual (in } 1 \\
\text { year) }\end{array}$ & $\begin{array}{l}\text { OECD (2016), } \\
\text { World Bank } \\
(2016)\end{array}$ \\
\hline Number of Nurses & $\begin{array}{l}\text { The number of nurses per } \\
1000 \text { individual (in } 1 \text { year) }\end{array}$ & $\begin{array}{l}\text { World Bank } \\
(2016)\end{array}$ \\
\hline Hospital Bed Number & $\begin{array}{l}\text { The number of hospital } \\
\text { bed per } 1000 \text { individual (in } \\
1 \text { year) }\end{array}$ & $\begin{array}{l}\text { OECD (2016), } \\
\text { World Bank } \\
(2016)\end{array}$ \\
\hline $\begin{array}{l}\text { Life Expectancy at } \\
\text { Birth (LEB) }\end{array}$ & $\begin{array}{l}\text { Average life expectancy } \\
\text { for a new born }\end{array}$ & $\begin{array}{l}\text { World Bank } \\
\text { (2016) }\end{array}$ \\
\hline $\begin{array}{l}\text { Mother Mortality } \\
\text { Rate (MMR) }\end{array}$ & $\begin{array}{l}\text { Mother mortality rate in } \\
\text { every } 100,000 \text { live birth }\end{array}$ & $\begin{array}{l}\text { World Bank } \\
\text { (2015) }\end{array}$ \\
\hline $\begin{array}{l}\text { Health Expenditure } \\
\text { per Capita (HEPC) }\end{array}$ & $\begin{array}{l}\text { Health expenditure } \\
\text { per person per year } \\
\text { (purchasing power parity } \\
-\$ \text { ) }\end{array}$ & $\begin{array}{l}\text { World Bank } \\
\text { (2015) }\end{array}$ \\
\hline $\begin{array}{l}\text { Tobacco } \\
\text { Consumption }\end{array}$ & $\begin{array}{l}\text { Tobacco Consumption } \\
\text { among the Population } \\
\text { over } 15 \text { years of age every } \\
\text { day (\%) }\end{array}$ & $\begin{array}{l}\text { World Bank } \\
\text { (2016) }\end{array}$ \\
\hline $\begin{array}{l}\text { Alcohol } \\
\text { Consumption }\end{array}$ & $\begin{array}{l}\text { Alcohol consumption } \\
\text { per person over } 15 \text { years } \\
\text { (Liters) (within } 1 \text { year) }\end{array}$ & WHO (2016) \\
\hline Obesity Rate & $\begin{array}{l}\text { Adult population with } \\
\text { body mass index of } 30 \text { or } \\
\text { more (\%) }\end{array}$ & WHO (2016) \\
\hline $\begin{array}{l}\text { Public Education } \\
\text { Expenditure }\end{array}$ & $\begin{array}{l}\text { Share of public education } \\
\text { expenditure in Gross } \\
\text { Domestic Product (GDP) } \\
\text { (\%) }\end{array}$ & $\begin{array}{l}\text { World Bank } \\
\text { (2015) }\end{array}$ \\
\hline $\begin{array}{l}\text { Primary School } \\
\text { Registration Rate }\end{array}$ & $\begin{array}{l}\text { Proportion of enrolled } \\
\text { primary school enrollment } \\
(\%)\end{array}$ & $\begin{array}{l}\text { World Bank } \\
\text { (2016) }\end{array}$ \\
\hline $\begin{array}{l}\text { Primary School } \\
\text { Teacher/student } \\
\text { Ratio }\end{array}$ & $\begin{array}{l}\text { The ratio of the number of } \\
\text { primary school students } \\
\text { to the number of teachers } \\
(\%)\end{array}$ & UNESCO (2016) \\
\hline
\end{tabular}

As a result of the literature review conducted, the most used health indicator variables in health system performance measurement and clustering analysis studies were the number of physician, nurse and bed per specific population, life expectancy at birth, maternal mortality rate, infant mortality rate and per capita health expenditure $(16-18,22,23)$. In this study, these variables which are frequently used in the literature, were used. 
The second clustering analysis was conducted with behavioral risk factors that had a direct effect on national health systems in many studies. In the third clustering analysis, educational variables, which are thought to have effects on health system performance in many studies $(3,6,24-27)$, were investigated. Obesity ratio, smoking and alcohol consumption are the variables used within the scope of behavioral risk factors. The ratio of public education expenditure to GDP, the rate of enrollment to primary education and the ratio of the number of primary school students to the number of teachers are the variables of education used together with the health indicators in the clustering analyzes.

Statistical Package for the Social Sciences (SPSS) version 22.0 was used to analyze the data obtained. The clustering analysis method was used to group the outcomes of health and educational variables of EU member and candidate countries. Clustering analysis is used to evaluate clusters rather than data. In clustering analysis, ungrouped data is grouped according to similarities. These grouped data constitute clusters and are expected to show homogeneous cluster inside and heterogeneous appearance among themselves (28).

Variables should be standardized so that each variable's contribution to distance can be at the same level (29). The data used in this study are standardized by $Z$ standardization method. In this study, Ward Method, which is one of the hierarchical clustering analysis methods, was used. Sequential Euclidean Distance Measure was chosen as the distance measure of the Ward Method. In the hierarchical clustering method, all data are collected in a single group by forming a tree-like structure. Then, groups are divided into groups and the other groups are formed until they become indivisible (30). Sets are created using the connection methods used to calculate the mathematical distance measure between the data points and possible sets. Ward Method is one of these connection methods (31). In the Ward technique, the mean distance to the observations in the same cluster is based on the observation of the middle of the cluster. Also, in the Ward Method, clusters are formed to minimize the variance within the cluster (32). One-way Analysis of Varriance (ANOVA) test was used to determine whether the clusters exhibited a heterogeneous distribution.

\section{Results}

As a result of clustering analysis using health indicators (the number of physician, nurse and bed per 1,000 people, life expectancy at birth, maternal mortality rate, infant mortality rate and per capita health expenditure), 4 clusters were formed. Clusters of countries are given in Table 2. Cluster A includes all EU candidate countries and three countries joined EU in fifth expansion (Turkey, Albania, Macedonia, Hungary, Bosnia and Herzegovina, Montenegro, Latvia, Serbia and Romania). In the Cluster $B$, most of the former Eastern Bloc and the countries which joined EU in the fifth enlargement process (Poland, Slovakia, Estonia, Lithuania, Bulgaria, Czech Republic and Croatia) are included. The Cluster $\mathrm{C}$ includes the Benelux countries (Belgium, the Netherlands, and Luxembourg) and the Central and Western European countries (Ireland, the United Kingdom, Denmark, Sweden, Finland, France, Germany, Austria, Slovenia and Malta). Mediterranean countries constitute the Cluster D (Cyprus, Greece, Spain, Italy and Portugal).

\begin{tabular}{|c|c|c|c|}
\hline Cluster A & Cluster B & Cluster C & Cluster D \\
\hline Turkey & Poland & Netherlands & Cyprus \\
\hline Albania & Slovakia & Ireland & Greece \\
\hline Macedonia & Estonia & United Kingdom & Spain \\
\hline Hungary & Lithuania & Belgium & Italy \\
\hline Bosnia Herzegovina & Bulgaria & Luxembourg & Portugal \\
\hline Montenegro & Czech Republic & Denmark & \\
\hline Latvia & Croatia & Sweden & \\
\hline Serbia & & Finland & \\
\hline \multirow[t]{5}{*}{ Romania } & & France & \\
\hline & & Germany & \\
\hline & & Austria & \\
\hline & & Slovenia & \\
\hline & & Malta & \\
\hline
\end{tabular}

Table 3 shows the ANOVA test for the health indicators of the clusters. As a result of the clustering analysis, the clusters are expected to be homogeneous in their respective clusters and heterogeneous between clusters. According to the ANOVA test results, it can be said that health indicator results are statistically significant and that the clusters provide homogeneity inside clusters and heterogeneity among them. When the overall rankings of the clusters 
are examined by health indicators, it is determined that the countries in the $C$ and $D$ clusters have the best health indicators. It was determined that the countries in the Cluster B were in the second place and the countries in the Cluster A were in the last place.

\begin{tabular}{|c|c|c|c|c|c|c|c|}
\hline Variables & Type & $\begin{array}{c}\text { Cluster } \\
\text { A }\end{array}$ & $\begin{array}{c}\text { Cluster } \\
\text { B }\end{array}$ & $\begin{array}{c}\text { Cluster } \\
\text { C }\end{array}$ & $\begin{array}{c}\text { Cluster } \\
\text { D }\end{array}$ & $\mathrm{F}$ & $\mathrm{p}^{*}$ \\
\hline \multirow{2}{*}{$\begin{array}{l}\text { Number of } \\
\text { Physicians }\end{array}$} & Value & 2.50 & 3.55 & 3.50 & 4.60 & \multirow{2}{*}{8.354} & \multirow{2}{*}{$<0.001$} \\
\hline & Rank & 4 & 2 & 3 & 1 & & \\
\hline \multirow{2}{*}{$\begin{array}{l}\text { Number of } \\
\text { Nurses }\end{array}$} & Value & 4.95 & 6.61 & 11.45 & 5.00 & \multirow{2}{*}{26.179} & \multirow{2}{*}{$<0.001$} \\
\hline & Rank & 4 & 2 & 1 & 3 & & \\
\hline \multirow{2}{*}{$\begin{array}{l}\text { Hospital } \\
\text { Bed } \\
\text { Number }\end{array}$} & Value & 4.70 & 6.22 & 4.56 & 3.44 & \multirow{2}{*}{3.571} & \multirow{2}{*}{0.025} \\
\hline & Rank & 2 & 1 & 3 & 4 & & \\
\hline \multirow{2}{*}{ LEB } & Value & 76.34 & 77.01 & 81.69 & 81.98 & \multirow{2}{*}{50.779} & \multirow{2}{*}{$<0.001$} \\
\hline & Rank & 4 & 3 & 2 & 1 & & \\
\hline \multirow{2}{*}{ MMR } & Value & 17.11 & 7.28 & 6.92 & 5.80 & \multirow{2}{*}{10.091} & \multirow{2}{*}{$<0.001$} \\
\hline & Rank & 4 & 3 & 2 & 1 & & \\
\hline \multirow{2}{*}{ HEPC } & Value & 1160.11 & 1878.00 & 4736.69 & 2707.20 & \multirow{2}{*}{57.175} & \multirow{2}{*}{$<0.001$} \\
\hline & Rank & 4 & 3 & 1 & 2 & & \\
\hline \multicolumn{2}{|c|}{ Overall rank } & 3 & 2 & 1 & 1 & & \\
\hline
\end{tabular}

Table 4 shows the results of clustering analysis by adding behavioral risk factors variables (alcohol consumption, smoking, obesity rate) to health indicators. As a result of clustering analysis, five clusters were formed. Cluster A includes two EU candidate countries (Turkey and Albania). Cluster B includes Macedonia, Slovakia, Estonia, Poland, Bosnia and Herzegovina, Montenegro, Cyprus, Croatia and Greece and Cluster C includes Lithuania, Bulgaria, Latvia, Hungary, Serbia, Romania and the Czech Republic, both of $B$ and $C$ include mainly the countries which are involved in the last enlargement process and located in Eastern Europe. Most of the countries in the Western and Mediterranean (Netherlands, the United Kingdom, Slovenia, Malta, Denmark, Sweden, Finland, Spain, Italy and Portugal) are located in the Cluster D. The Cluster E consists of EU founding members (Belgium, Luxembourg, France and Germany) and Ireland and Austria.
Table 4. Clustering Analysis according to Health Indicators and Behavioral Risk Factors

\begin{tabular}{|c|c|c|c|c|}
\hline Cluster A & Cluster B & Cluster C & Cluster D & Cluster E \\
\hline Turkey & Macedonia & Lithuania & Netherlands & Ireland \\
\hline Albania & Slovakia & Bulgaria & $\begin{array}{c}\text { United } \\
\text { Kingdom }\end{array}$ & Belgium \\
\hline & Estonia & Latvia & Slovenia & Luxembourg \\
\hline & Poland & Hungary & Malta & France \\
\hline & $\begin{array}{c}\text { Bosnia } \\
\text { Herzegovina }\end{array}$ & Serbia & Denmark & Germany \\
\hline & Montenegro & Romania & Sweden & Austria \\
\hline & Cyprus & $\begin{array}{c}\text { Czech } \\
\text { Republic }\end{array}$ & Finland & \\
\hline & Croatia & & Spain & \\
\hline & Greece & & Italy & \\
\hline & & & Portugal & \\
\hline
\end{tabular}

Table 5 shows the results of clustering analysis by adding educational indicators (public education expenditure, primary school enrollment rate, primary school student / teacher ratio) to health indicators. As a result of clustering analysis, five clusters were formed. Five EU candidate countries (Turkey, Albania, Macedonia, Bosnia and Herzegovina and Montenegro) and Romania, which became members in 2007, is located in the Cluster A. The majority of countries in the fifth enlargement process (Poland, Slovakia, Estonia, Lithuania, Bulgaria, Latvia, Hungary, Serbia and Croatia) came together in the Cluster B. Apart from Italy, the EU constituent countries (Netherlands, Belgium, Luxembourg, France and Germany) and most of Central and Western European countries (Ireland, United, Slovenia, Malta, Czech Republic and Austria) in the Cluster C. The Nordic countries (Denmark, Sweden and Finland) are placed in Cluster D. Finally, the Cluster E includes Mediterranean countries (Cyprus, Greece, Spain, Italy and Portugal).

Table 6 shows the general ranking of clusters based on behavioral risk factors and education related indicators added to health indicators in clustering analysis. As a result of clustering analysis carried out by adding behavioral risk factors to health indicators, it was determined that $D$ and E clusters had the best health and behavioral risk factor indicators. It was found that Cluster B was the second, C, and the A clusters become the third respectively. 


\begin{tabular}{|c|c|c|c|c|}
\hline Cluster A & Cluster B & Cluster C & Cluster D & Cluster E \\
\hline Turkey & Slovakia & Netherlands & Denmark & Cyprus \\
\hline Albania & Estonia & Ireland & Sweden & Greece \\
\hline Macedonia & Poland & $\begin{array}{c}\text { United } \\
\text { Kingdom }\end{array}$ & Finland & Spain \\
\hline $\begin{array}{c}\text { Bosnia } \\
\text { Herzegovina }\end{array}$ & Bulgaria & Slovenia & & Italy \\
\hline Montenegro & Latvia & Belgium & & Portugal \\
\hline \multirow[t]{6}{*}{ Romania } & Lithuania & Luxembourg & & \\
\hline & Hungary & Malta & & \\
\hline & Serbia & $\begin{array}{c}\text { Czech } \\
\text { Republic }\end{array}$ & & \\
\hline & Croatia & France & & \\
\hline & & Germany & & \\
\hline & & Austria & & \\
\hline
\end{tabular}

As a result of clustering analysis carried out by adding educational variables to health indicators, it was found that the Cluster $D$ formed by Nordic countries had the best indicator scores. The Cluster E formed by the Mediterranean countries took the second place. The cluster formed of EU founding members, Central and Western European countries in the third place. In the last enlargement process, the Cluster A, in which the EU cluster is located, is the fourth and the Cluster A, which is the EU candidate country, is the last.

\begin{tabular}{|c|c|c|c|c|c|c|}
\hline Variables & Type & $\begin{array}{c}\text { Cluster } \\
\text { A }\end{array}$ & $\begin{array}{c}\text { Cluster } \\
\text { B }\end{array}$ & $\begin{array}{c}\text { Cluster } \\
\text { C }\end{array}$ & $\begin{array}{c}\text { Cluster } \\
\text { D }\end{array}$ & $\begin{array}{c}\text { Cluster } \\
\text { E }\end{array}$ \\
\hline $\begin{array}{l}\text { Health } \\
\text { Indicators }\end{array}$ & Rank & 3 & 2 & 1 & 1 & - \\
\hline $\begin{array}{l}\text { Health } \\
\text { Indicators } \\
+ \\
\text { Behavioral } \\
\text { Risk } \\
\text { Factors }\end{array}$ & Rank & 4 & 2 & 3 & 1 & 1 \\
\hline $\begin{array}{l}\text { Health } \\
\text { Indicators } \\
+ \\
\text { Education } \\
\text { Indicators }\end{array}$ & Rank & 5 & 4 & 3 & 1 & 2 \\
\hline
\end{tabular}

\section{Discussion and Conclusions}

Clustering analysis can be seen as one of the ways to gain insight into the performance of countries' health systems. When the literature is examined, various studies on this subject can be found. For example; in the study of Wendt (2009), health systems performance of European countries is compared with clustering analysis by using indicators related to performance, financing, service delivery and access to service (16). In the study of Klomp and Haan (2010), the health system performance of 171 countries was compared with clustering analysis using indicators related to performance, survival, infectious and noninfectious diseases, health workers, hospital bed numbers and immunization rates (17). In the study of Miszczyńska (2013) health system performance of 21 EU member states were compared with indicators such as, financing (health expenditures), health care services (number of physicians and hospital beds) and health status (perceived health status and life expectancy at birth) using clustering analysis (19). In the study of Teleş et al., (2018), the health system performance of 36 European countries were compared in terms of financing (health expenditures), health care resources (number of physicians, number of nurses and number of hospital beds) and health status indicators (expected life expectancy at birth, mean length of stay, infant mortality rate and mother) mortality rate with clustering analysis (22).

The study of Proksch et al. (2019), which compares the health system of 30 OECD countries with cluster analysis for innovative output generating performance, is similar to this study in terms of methodology and in terms of incorporating more than one clustering analysis (23). In the study of Proksch et al. (2019), health expenditure, number of physicians and hospital beds, labor force ratio employed in health sector, number of computed tomography (CT) and magnetic resonance (MR), number of applications to physician, length of hospital stay and rate of over 65 age group were used. In the study, some variables (patents, number of scientific publications, high technology product exports) were added to output variables and how addition of these affected the clusters is reported (23).

In this study, health system performance of member and candidate countries of EU is examined by using indicators related to behavioral risk factors and education. In this context, with clustering analysis, health performance of 
EU member and candidate countries were compared. First, a clustering analysis with only health indicators was conducted, and then whether behavioral risk factors and indicators related to education affected the clusters formed as a result of the first clustering analysis was determined.

In the clustering analysis using only health indicators, 4 clusters emerged. When these clusters are analyzed, it is seen that mostly EU member and EU candidate countries form a cluster. The former eastern bloc countries, central European countries and Mediterranean countries formed separate clusters. At this point, in addition to the health care services provided, the style of management and geography can be interpreted as affecting health indicators.

As a result of the clustering analysis with the addition of behavioral risk factors, 5 clusters have emerged. When these clusters are analyzed, both predominantly Muslim countries (Turkey and Albania) seems to form a cluster. It is thought that the prohibition of behavioral risk factors such as alcohol and cigarettes by Islamic religion has laid the ground for the existence of these two countries in the same cluster. There are some studies supporting this view in the literature $(39,40)$. When the other clusters are examined, it is seen that the old eastern bloc countries with high alcohol and cigarette consumption are concentrated in two different clusters. The developed central and western European countries are also concentrated in two clusters. These countries have similar health indicators and behavioral risk factors. Behavioral risk factors, although they are individual preferences, may require the imposition of some restrictions since these risk factors cause some level of negative externality, as well as poses risks towards the society.

It is observed that 5 clusters are formed in clustering analysis with addition of indicators related to education to health indicators. When these clusters are examined, it is seen that a cluster of mostly EU candidate countries, a cluster of former Eastern bloc countries, a cluster of developed central European countries, a cluster of some Scandinavian countries and a cluster of Mediterranean countries were formed. Considering that education is one of the main factors affecting health status, it is recommended that countries that want to improve their health indicators should give importance to educational services together with health care services.
In this study, the effects of behavioral risk factors and educational indicators on health systems of countries are presented with clustering analysis. It was observed that behavioral risk factors and educational indicators caused changes in clustering of countries. In this context, countries that wish to improve their health status should consider the impact of behavioral risk factors and educational factors on health indicators.

\section{References}

1. WHO (World Health Organization). The World Health Report 2000. Health Systems: Improving Performance. Geneva: World Health Organization; 2000.

2. Noto G, Corazza I, Kl̦avina K, et al. Health system performance assessment in small countries: The case study of Latvia. Int J Health Plann Mgmt. 2019;1-15.

3. Smith PC, Mossialos E, Papanicolas I, et al. Performance Measurement for Health System Improvement. New York: Cambridge University Press; 2009.

4. Anderson G, Hussey PS. Comparing health system performance in OECD countries. Health Affairs. 2001; 20(3): 219-232.

5. Lalonde M. A New Perspective on the Health of Canadians. Ottawa: Government of Canada; 1974.

6. Samut PK, Cafri R. Analysis of the efficiency determinants of health systems in OECD countries by DEA and Panel Tobit. Social Indicators Research. 2016; 129:113-132.

7. Çetin VR, Bahçe S. Measuring the efficiency of health systems of OECD countries by data envelopment analysis. Applied Economics. 2016; 48(37): 3497-3507.

8. Liu Y, Rao K, Wu J, et al. China's health system performance. The Lancet. 2008; 372(9653): 1914-1923.

9. McIntyre D, Rogers L, Heier EJ. Overview, history, and objectives of performance measurement. Health Care Financing Review. 2001; 22(3): 7-43.

10. Loeb JM. The current state of performance measurement in healthcare. International Journal for Quality in Health Care. 2004 16(Suppl. 1): 5-9.

11. Tandon A, Murray CJ, Lauer JA, et al. Measuring Overall Health System Performance for 191 Countries. Geneva: World Health Organization; 2000.

12. Power M. The Audit Society: Rituals of Verification. Oxford: Oxford University Press; 1999.

13. Smith PC. Performance measurement in health care: history, challenges and prospects. Public Money \& Management. 2005 25(4): 213-220.

14. Boerma T, Chopra M, Evans D. Health systems performance assessment in the bulletin. Bulletin of the World Health Organization. 2009; 87(1): 2-2A.

15. Ozcan YA. Healthcare Benchmarking and Performance Evaluation. 2nd edn New York: Springer; 2014.

16. Wendt C. Mapping European healthcare systems: a comparative analysis of financing, service provision and access to healthcare. Journal of European Social Policy. 2009; 19(5): 432-445.

17. Klomp J, Jakob de H. Measuring health: a multivariate approach. Social Indicators Research. 2010; 96(3): 433-457.

18. Muntaner C, Haejoo C, Joan B, et al. Hierarchical cluster analysis of labour market regulations and population health: a taxonomy of low-and middle-income countries. BMC Public Health. 2012; 12(1): $1-15$. 
19. Miszczyńska K. Multivariate analysıs of healthcare systems in selected European Unıon countries: Cluster analysis. Quantitative Methods in Economics. 2013;14(2): 99-107.

20. Tanaka OY, Drumond JM, Cristo EB, et al. Cluster analysis as a tool for management improvement in the SUS. Saúde e Sociedade. 2015; 24(1): 34-45.

21. Sonğur $C$, Top $M$. Regional clustering of medical imaging technologies. Computers in Human Behavior. 2016; 61: 333-343.

22. Teleş $M$, Konca M, Çakmak C. Comparison of Health Systems Performance of Countries in the European Union Cycle. Manisa Celal Bayar University Journal of Management and Economics. 2018; 25(3): 811-835.

23. Proksch D, Busch-Casler J, Haberstroh MM, et al. National health innovation systems: Clustering the OECD countries by innovative output in healthcare using a multi indicator approach. Research Policy. 2019; 48(1): 169-179.

24. Lopez AD, Mathers CD, Ezzati M, et al. Global Burden of Disease and Risk Factors. USA: The World Bank; 2006.

25. Pronk NP, Anderson LH, Crain AL, et al. Meeting recommendations for multiple healthy lifestyle factors: prevalence, clustering, and predictors among adolescent, adult, and senior health plan members. American Journal of Preventive Medicine. 2004; 27(2): 25-33.

26. Todaro MP, Smith SC. Economic Development. Boston: Pearson; 2015.

27. Murray C, Evans D. Health Systems Performance Assessment: Debates, Methods and Empiricism. Geneva: World Health Organization; 2013.

28. Kaufman L, Peter JR. Finding Groups in Data: An Introduction to Cluster Analysis. USA: John Wiley \& Sons; 2009.

29. Alpar R. Multivariate Statistical Methods. Ankara: Detay Publishing; 2013.

30. Hair JF, Babin BJ, Anderson RE, et al. Multivariate Data Analysis. Essex: Pearson, 2014.

31. Clatworthy J, Deanna B, Matthew $\mathrm{H}$, et al. The use and reporting of cluster analysis in health psychology: A review. British Journal of Health Psychology. 2005; 10(3): 329-358.

32. Punj G, Stewart DW. Cluster analysis in marketing research: Review and suggestions for application. Journal of Marketing Research. 1983; 20(2): 134-148.

33. Cylus J, Papanicolas I, Smith PC. Using data envelopment analysis to address the challenges of comparing health system efficiency. Global Policy. 2017; 8(Supplement 2): 60-68.

34. Afonso A, St. Aubyn M. Assessing health efficiency across countries with a two-step and bootstrap analysis. Applied Economics Letters. 2011; 18(15): 1427-1430.

35. 35. Moran V, Jacobs R. An international comparison of efficiency of Inpatient mental health care systems. Health Policy. 2013; 112(1-2): 88-99.

36. Asghar N, Rehman HU, Ali M. Cost productivity of healthcare systems in OIC's member countries: An application of cost Malmquist Total Productivity Index. Review of Economics and Development Studies. 2019; 5(3): 461-468.

37. Ahmed $\mathrm{S}$, Hasan MZ, MacLennan M et al. Measuring the efficiency of health systems in asia: A data envelopment analysis. BMJ Open. 2019; 9: e022155.

38. Castaldo A, Antonelli MA. Determinants of health sector efficiency: Evidence from a two-step analysis on 30 OECD countries. Economics Bulletin. 2020; 40(2): 1651-1666.

39. WHO. Global Status Report on Alcohol and Health 2018. WHO; 2019.

40. Varol M. Alkol raporu. İstanbul: Türkiye Yeşilay Cemiyeti; 2011. 